\title{
An Overview and Discussion of Solution Proposals for Sustainable Agriculture and Food Security in Sub-Sahara Africa
}

\author{
Linda Kleemann ${ }^{1}$ \\ ${ }^{1}$ Kiel Institute for the World Economy, Hindenburgufer 66, 24105 Kiel, Germany \\ Correspondence: Linda Kleemann, Kiel Institute for the World Economy, Hindenburgufer 66, 24105 Kiel, \\ Germany. E-mail: linda.kleemann@ifw-kiel.de
}

Received: May 3, 2013 Accepted: August 10, 2013 Online Published: August 16, 2013

doi:10.5539/sar.v2n4p48 URL: http://dx.doi.org/10.5539/sar.v2n4p48

\begin{abstract}
The development of the agricultural sector and the improvement of the food security situation are seen as essential components to sustainable development in Sub-Sahara Africa. However, continuing population growth, impacts of climate change and environmental degradation add to an unprecedented combination of pressures that threaten existing efforts and solutions. This article discusses the relation between the challenges of making agriculture more sustainable and meeting food security needs. Several solutions proposals are discussed and organic farming as one of them is used to develop decision criteria. Due to its involvement of all three dimensions of sustainable development, economic, social and environmental organic farming could be one possible approach to create a more sustainable agricultural system.
\end{abstract}

Keywords: sustainable agriculture, organic agriculture, food security

\section{Introduction}

When the agricultural system is sustainable, it should by definition be able to assure the food security of a population by producing enough food. However, hunger and malnutrition are not just a problem of food availability, but also a problem of access to food. As argued by Sen (1999), people suffer from hunger when they cannot establish their entitlement over an adequate amount of food. Thus, to eliminate hunger and malnutrition, it is not only crucial to understand how policies can increase food production but also how they can ensure an equitable distribution of produced food, as well as safeguard the resources needed for production.

Improvements in the current food security situation and in the local agricultural sector, such as increasing the productivity of smallholder farming and the effective use of large farms to meet dietary needs of the poor rural population, are essential to foster sustainable development in Sub-Sahara Africa. Their state strongly influences other sectors of the economy. Both policy makers and analysts acknowledge the need for improving agricultural productivity and in boosting food security in Sub-Sahara Africa. Progress in achieving food security is also a prerequisite to achieving the Millennium Development Goals (MDGs) (Note 1). From the African perspective, the fight against hunger is the most pressing social challenge. On the production side, it is of dire importance to increase the productivity of smallholder farming and the more effective use of large farms to meet the dietary needs of the rural poor. At the same time, it is also necessary to reduce the environmental impacts of the agricultural sector so as to not destroy its own ecological foundations. In many parts of Sub-Sahara Africa, the land is already strongly degraded. The agricultural successes of the recent decades, with their methods of increasing productivity by use of mineral fertilizers and pesticides, have damaged the foundations of the long-term productivity of the land (IAASTD, 2009).

A number of factors put pressure on both food security and sustainability of agriculture. According to the IAASTD, the global demand for grain will increase by $75 \%$ from 2000 to 2050 (IAASTD, 2009). Hence, a dwindling amount of water and soil must feed more people and supply fodder for meat production as well as produce biomass for the chemical industry and energy generation. This raises the pressure on an already precarious food supply and on the sustainability of its production system, especially in Sub-Sahara Africa.

The problem of long-term food security appears to be compounded by the effects of climate change, large-scale investments in agricultural land, and highly volatile world market prices, especially for staple foods. Multiple reciprocal cause-effect relationships complicate the ability to make a clear-cut statement of causality. Large-scale 
land investments for instance may increase food production and hunger in a given country simultaneously, when the production is exported. This is just one example. Food production represents a classic system dynamics case with multiple stakeholders, interdependencies and processes that affect the overall system performance. In this system structural factors and interdependencies are difficult to identify and vary over time, such as in the case of land use for cultivation of biofuels. Sub-system causal relationships are easier to identify, such as the expansion of the world population and changing consumer habits, which lead to an increase in the demand for meat products (von Braun et al., 2008) (Note 2). Therefore instead of using one-for-all approaches, more feasible strategies may be based on a combination of sub-systems analysis with integrated feedback loops to other sub-systems.

For this article the literature on this topic over the last 15 years was reviewed in the search for those challenges and solution proposals that persist. Drawing on the results from the literature review, this article shows the relation between the challenges of making agriculture more sustainable and meeting food security in Sub-Saharan Africa. Using solution proposals as an entry point, it evaluates them by their potential effects on sustainability in agriculture and food security and develops decision criteria. Due to its involvement of all three dimensions of sustainable development, economic, social and environmental organic farming is presented as one possible promising approach.

The paper is structured as follows. The next section discusses the concept of sustainability, as well as the three dimensions of sustainability. This is followed by an outline of the agricultural and food security challenges in Sub-Saharan Africa. The fourth section discusses the strategies employed to promote sustainable food production in the region and how this affects food security. The final section presents concluding remarks and implications.

\section{Sustainable Agriculture and Food Security}

\subsection{Is Sub-Sahara Africa's Food Security Situation Sustainable?}

Food security is defined by the World Health Organization as existing when all people at all times have access to sufficient, safe, nutritious food to maintain a healthy body and active life. The food security and nutrition situation in Sub-Saharan Africa is clearly not sustainable. Even though the progress report from the United Nations on the Millennium Development Goals discloses that the number of people living in absolute poverty in developing countries has declined from 1.8 billion in 1990 to 1.2 billion in 2010, the regional and intra-African distribution of poverty is highly heterogeneous: in Sub Saharan Africa - the world region with the highest poverty rate $-49 \%$ of the population lived in absolute poverty in 2010; in South Asia that number was at $31 \%$ of the population; in the Latin American-Caribbean region, 6\%, and in Northern Africa it is at 3\% of the population (World Bank, 2013).

Poverty can hinder the acquisition of sufficient quantities of food and affects both the urban and rural population. In the latter, poverty can prevent improvements in productivity when inputs cannot be purchased. Labor productivity is also low due to little educational opportunities and inadequate access to health care and/or malnutrition leading a vicious cycle of poverty and hunger.

While the proportion of hungry people in the world has declined recently, the absolute number has increased (according to data from FAOSTAT). According to statistics from the UNSCN, the southern Africa region with 239 million hungry people comes second after the Asia Pacific region with 578 million. However, the number of hungry people in Asia has decreased over the past 20 years while it has increased by $40 \%$ in Africa. In percentage terms Sub-Saharan Africa leads the way with 25\% malnourishment. Accordingly, the World Hunger Index (WHI)(Note 3) prepared by the International Food Policy Research Institute (IFPRI), Concern Worldwide, and Welthungerhilfe (2011), also shows the worst picture for Southern Africa and the worst country case examples are also in Africa: Congo, Burundi, Eritrea and Chad, where continuing conflict and political instability worsen the situation.

Beyond the mere lack of calories, the problem of food insecurity also includes the so-called hidden hunger; that is malnutrition due to nutrient deficiencies, such as vitamin and mineral deficiencies. These are mostly associated with other health problems (von Braun, 2001)(Note 4). Again Africa is the largest region in the world with a high nutrient deficiency. On a global scale, deficiencies in iodine affect an estimated two billion people worldwide, zinc (1.2 to 2 billion), iron ( 0.8 to 1.2 billion), and Vitamin A, that can cause blindness (200 million), are the most common. Many people suffer from multiple micronutrient deficiencies.

The problem of food security in Sub-Sahara Africa is as much a problem of quantity as a question of access. Taking the current world harvest as basis, there is theoretically more than sufficient energy available globally, namely the equivalent of about 800 grams of grain per day (Flachowski, 2011) (Note 5). Nonetheless, this 
amount is distributed extremely unequally. Africa imports far more food than it exports (Figure 1) and the quantity of imports has increased significantly over the last five decades, as per-capita food production has continuously declined (Mc Arthur, 2011). Inaccessible rural areas and areas of conflict are particularly underserved. The presence of adequate amount of food and nutrients is therefore a necessary but not a satisfactory condition for food security.

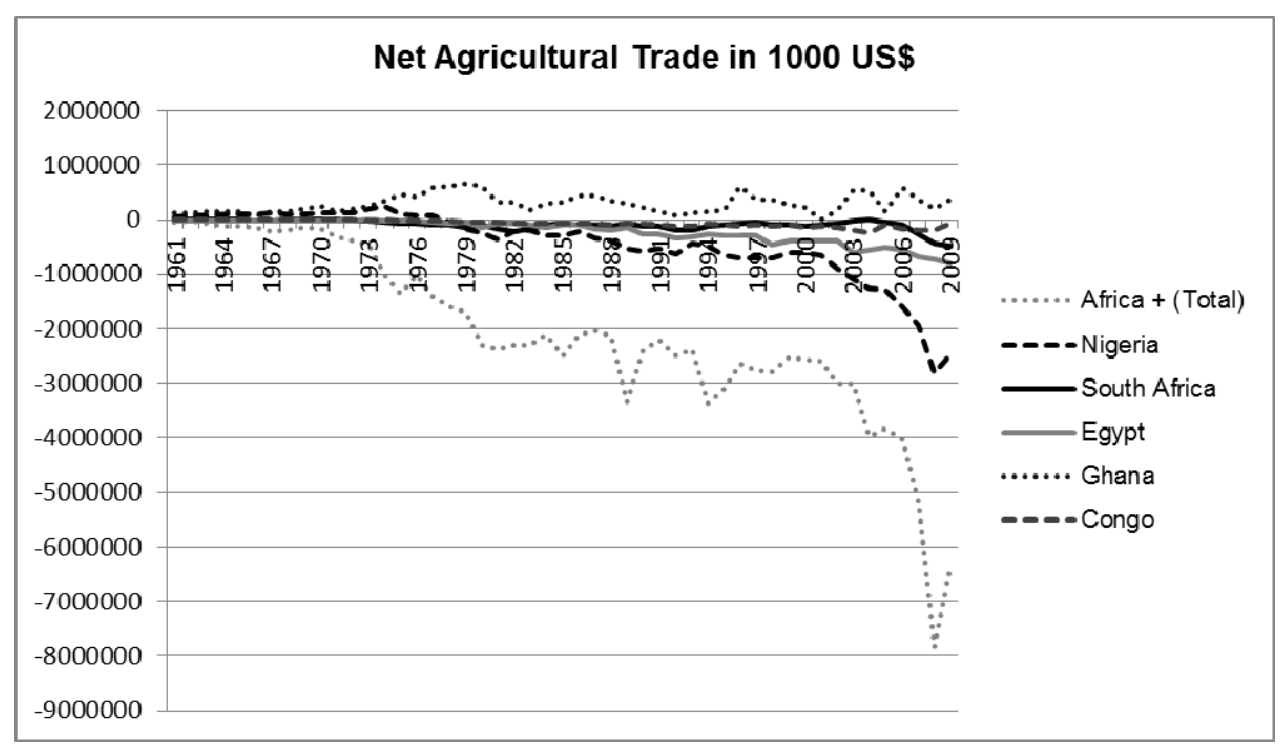

Figure 1. Difference in Exports and imports in trade of agricultural goods in Africa 1961- 2009

Source: own representation, statistics from FAOSTAT.

There are two types of access to food: self-sufficiency and markets. As a result of poverty, subsistence farmers are unable to feed themselves because they have insufficient factors of production at their disposal. Under these circumstances, they are just as dependent as the urban population on the purchase of food. These parts of the population at risk of hunger or already food insecure are particularly vulnerable to changes in food markets. The most obvious example is price increases. The average African spends 50-80\% of his income on food, compared to $12 \%$ for the average German. Under these circumstances, rising food prices lead to reduced intake of calories and/or a reduction in the quality and diversity of food. Often animal products, fruits and vegetables are replaced by cheaper grains (UNSCN, 2010). Table 1 shows the enormous differences in caloric intake and consumption of food of animal origin. It is noteworthy to mention that the minimum in all the above mentioned categories is in Africa.

Table 1. Energy and protein consumption per person (extremes, means, and Germany for reference; data from 2005)

\begin{tabular}{|c|c|c|c|c|}
\hline & Min & Average & Max & Germany \\
\hline $\begin{array}{l}\text { Energy } \\
\text { (Mcal/person/day) }\end{array}$ & $\begin{array}{c}1.5 \\
\text { (DR Kongo) }\end{array}$ & 3 & $\begin{array}{c}3.9 \\
(\mathrm{USA})\end{array}$ & 3.5 \\
\hline $\begin{array}{l}\text { Part from Animal Origins } \\
(\% \text { of total })\end{array}$ & $\begin{array}{c}1.4 \\
\text { (DR Kongo) }\end{array}$ & 12.9 & $\begin{array}{c}32.6 \\
\text { (Island) }\end{array}$ & 20 \\
\hline $\begin{array}{l}\text { Protein from Animal Origins } \\
\text { (g/ person/day) }\end{array}$ & $\begin{array}{c}1.7 \\
\text { (Burundi) }\end{array}$ & 23.9 & $\begin{array}{c}69 \\
(\mathrm{USA})\end{array}$ & 52.8 \\
\hline $\begin{array}{l}\text { Eggs } \\
\text { (kg/ person/day) }\end{array}$ & $\begin{array}{c}0.1 \\
\text { (Burundi, } \\
\text { Central. Afr.-Rep.) }\end{array}$ & 9 & $\begin{array}{c}20.2 \\
\text { (China) }\end{array}$ & 11.8 \\
\hline $\begin{array}{l}\text { Milk } \\
\text { (kg/ person/day) }\end{array}$ & $\begin{array}{c}3.1 \\
\text { (DR Kongo) }\end{array}$ & 82.1 & $\begin{array}{c}367.7 \\
\text { (Sweden) }\end{array}$ & 248.7 \\
\hline
\end{tabular}


Source: adapted from Flachwoski (2011).

Some African countries suffer from the so-called 'double burden of hunger and obesity', i.e. the simultaneous problem of malnutrition and obesity and the resulting health issues. The background behind this problem lies with the adaption to the dietary habits and eating styles of the industrialized countries - the so-called 'nutrition transition' (Mendez \& Popkin, 2004).

\subsection{Sustainability in Agriculture in Sub-Sahara Africa}

Development is defined as sustainable according to the so-called Brundtland report when it 'meets the needs of the present without compromising the ability of future generations to meet their own needs' (UN WCED, 1987). Sustainable agriculture therefore stands for maximizing the productivity of the land and improving the well-being of people under the constraint of minimal damage to natural resources (land, water, air, and biodiversity) (Pretty, 1999). Agriculture is seen as a multifunctional system which includes the building of food security.

Sustainable agriculture has often been discussed in a controversial manner, with various authors suggesting different competing strategies to accomplish this goal. Pretty (1999) uses a capital-based model of agriculture, in which capital consists of natural, social, human, financial and physical capital, and provides services that underpin the agricultural system. Capital in this model is affected by politics, production processes and institutions. If this influence is successfully used, feedback processes will strengthen the capital base. If it is not successfully used, then it results for instance in environmental pollution or social tensions, which reduce the total capital stock. According to Pretty, a sustainable system increases the capital stock over time. Other authors assume that an absence of capital stock reduction is sufficient. Pearce (1988) keeps only the natural capital stock fixed. Availability of and access to the five different types of capital depends on contextual factors. These are divided into (short term) fixed factors (e.g. climate, agricultural ecology, soil and culture) and dynamic factors that can be externally influenced (e.g. legislation) (Pretty, 1999). The problem with models of this kind is the absence of a comparable measure for evaluating the different parts of the capital stock. Dimensions used to approximate such a measure are energy or monetary values, which again evokes the question of correct valuation. But even in a case where this would not be problematic, will a simultaneous increase in pollution and decrease in food insecurity by the same monetary amount be neutral?

In the three pillars of sustainability, economic sustainability ensures that farmers do not make any financial losses. This means, first, that his physical and financial capital, expressed in monetary units, does not decrease, which in turn is influenced by factors, such as prices, conditions of trade and yield that are considered in the following paragraphs in more detail.

The first factor, prices, opens up the question of whether high food prices help to promote African farmers. This cannot be easily answered. The price fluctuations of the past six years and the resulting scientific studies do not show a clear picture (Note 6). High prices can make farming in Sub-Sahara Africa more profitable and encourage investment in the sector. At the individual level, this is especially true for farmers who have enough land and access to adequate infrastructure, and are able to meet stringent international quality standards. Those who should benefit under the social aspect of sustainability, namely small and poor farmers lose from increasing prices, because they are mostly net food buyers (see for example Swinnen, 2011; World Bank, 2008). In the long term, they could also benefit if high prices lead to increased investment in food production and thereby to a higher production volume that is shared equitably. However, if part of the price increases and price volatility that can be traced back to speculation (Gilbert, 2010), affects all farmers negatively through increased uncertainty.

Second are conditions of trade. Small farmers in Sub-Sahara Africa have so far hardly benefited from the benefits of international agricultural trade because barriers are high between Sub-Sahara African countries and regulations for processed food in both developed countries hamper processing industries (IAASTD, 2009). Against the backdrop of growing markets for high quality and organic products in industrialized countries, new marketing channels are opening up. These can create new income opportunities under the condition that there is support for farmers to meet the required environmental regulations and quality standards.

Third, for economic sustainability with particular consideration to small farmers, framework conditions are particularly important. This concerns the physical infrastructure - especially transport routes, markets and storage facilities, the information infrastructure, and the institutional framework. Numerous studies emphasize the significance of contract security (for the reduction of transaction costs), and social safety nets (e.g. agricultural insurance) (Barrett et al., 2012). Also, land ownership or secure long-term leases are starting points to enable small farmers to escape out of poverty and malnutrition, since access to credit and investments in innovations and long-term measures, such as the preservation of soil fertility, are highly correlated to the security of land 
tenure (Abdulai et al., 2011).

The social dimension of sustainability in agriculture and nutrition is reflected in the justice, health, distribution, gender, and cultural aspects of society and is summarized in Pretty's model under social and human capital. Without long-term food security social sustainability is inconceivable. Increases in global food production will only lead to the alleviation of food insecurity, when the availability of food for the poor, through lower prices, higher incomes or better infrastructure, is improved. Measures to increase production volumes can even deteriorate access when vulnerable parts of the society are deprived of the opportunity for subsistence agriculture while new income opportunities for them are not created.

Against the backdrop of a growing global demand for resource-intensive food and renewable raw materials, a further intensification of agricultural production in Sub-Sahara Africa risks that its benefits are not used primarily to improve food security. One to two percent of global arable land is already used for energy crops and this number shows an upward trend (Dusseldorp \& Sauter, 2011). On social grounds, among the major causes of rural poverty and malnutrition are the unequal distribution of land and insecure land tenure rights and weak land governance (Fergussen, 2013; Anseuw \& Alden, 2010; Amanor, 2012). With the aim of formalizing land rights and counteracting unequal distribution, land reforms have been implemented in several Sub-Sahara African countries. However, not all have been successful and the ongoing relocation of peasants to make way for large-scale agricultural investment projects counteracts these efforts to distribute land more equally. Gender questions in land distribution have been largely disregarded. Land often has an important cultural value. The resulting emotional attachment forms part of the social dimension of sustainability.

The improvement of educational opportunities for the poor is one possible way to advance on social sustainability while combating hunger at the same time. A positive correlation between education level, income opportunities and nutritional status seems to be proven throughout the literature (Deaton 2003 provides a good summary). A virtuous cycle is set in motion because well-fed and, thus healthier people are better able to feed themselves adequately and have improved employment opportunities. To this adds the advantage of better education for agricultural production itself, in particular for increasing sustainability, since this means creating or applying new knowledge. Other mechanisms include social protection policies and the establishment and assurance of participatory change processes.

The final pillar of sustainability concerns natural capital, which is termed environmental sustainability. It is based strongly on the original ideas of sustainability, not to overexploit nature. In contrast to ecological sustainability, which is based on the capacity of ecosystems to maintain their essential functions over the long-term, environmental sustainability is based on the capacity of ecosystems to maintain their essential functions for future generations of mankind. I focus on this latter definition in this paper. An environmentally sustainable way of life would use the environment and natural resources only to an extent that these regenerate. In particular, the industrial high-yielding agriculture is often viewed as environmentally unsustainable as it is very input-intensive and dominated by large-scale monocultures. In accordance with Pretty's model, an environmentally sustainable agriculture would protect environmental resources, mainly land and water, in a way that their production capacity does at minimum not decrease. It further means that other ecological and environmental systems are protected in a way that they do not endanger the natural capital used in agriculture. If for instance beneficial organisms are eradicated by pollution from other sectors, this also affects agricultural sustainability. Similarly as climate change affects the basic parameters of agricultural sustainability. Thus, there are strong inter-linkages with other sectors.

To sum up, agriculture in Sub-Sahara Africa is sustainable when it ensures that the economic, environmental and social needs of current and future generations are met, including their food security needs. According to Pretty this means that the capital stock should increase over time, others demand that it at minimum does not decrease. As presented in this section, agriculture in Sub-Sahara Africa is unsustainable in many ways. Only few farmers are enabled to economic sustainability, for many the institutional framework impedes profitable production potentials. This includes the lack of social protection, of women's empowerment and of education which increase inequality and reduce social sustainability. Finally inefficient environmental regulation leads to environmental degradation through pollution, deforestation and exhaustion of land and water resources. The apparent food insecurity is a result of these problems.

\section{Reasons for the Current Situation in Sub-Sahara Africa}

The relationship between the three pillars of sustainability is particularly obvious in agriculture. If the soil is degraded, farming will not be economically productive. That is, it produces too little food. As a result, people suffer from hunger or malnutrition, which in turn leads to a destruction of natural resources. This implies that 
environmental sustainability is influenced not only by geographic and climatic factors and changes in agricultural technologies, but also by political, social and economic terms. These factors are discussed in this section.

Starting with geographical conditions, a large part of Africa's climate is considered not well suited for agriculture, a reason often given for its long history of famines. This is expressed as a limited availability of natural resources, especially water, even though Sub-Sahara Africa is rich in many other natural resources.

For instance land is not generally considered a limiting factor for the Sub-Sahara African agricultural landscape. Large stretches of land have so far hardly been put into agricultural use. However, only $10 \%$ of the land is truly fertile (UNEP, 2008a) and 13-16\% of the arable land has been damaged from erosion or been degraded as a result of other chemical and physical changes, such as infrastructure, cities, and pollutants (Bai et al., 2008). A recent study by von Braun et al. (2011) shows that about $17 \%$ of the agricultural production in Sub-Saharan Africa is lost due to land degradation, in some regions up to $40 \%$, and on average $8 \%$ throughout the continent. This consequently leads to an increasing use of moderately arable soils. Forests, which cover about $20 \%$ of the African landscape, are strongly deforested. The deforestation rate is more than four million hectares per year, twice the world average (Kelatwang \& Garzuglia, 2006).

Rapid population growth raises the pressure on the forests and already heavily farmed areas. Almost the entire global population growth in the next couple of years will, according to calculations done by the United Nations, take place in developing countries. This will increase the populations in many African countries by more than $50 \%$. Through this population surge, the amount of theoretically available arable land per person is predicted to decline from 4.7 hectares per person in 1970 to 1.5 in 2050. In reality, this may occur faster than predicted in the model, since competition from renewable resources and settlements must be considered in the equation. Due to the fact that settlements are often located in fertile river valleys and coastal plains, some of the best agricultural land is converted almost irreversibly into cities and roads.

Africa is the warmest and second-driest continent, making water a limiting factor in the expansion of the agricultural landscape. Water is as much a staple food as a basis for food production. With an average share of $70 \%$, in some African countries even above $90 \%$ agriculture uses the most amount of water. This water use is not environmentally sustainable if the rate of use exceeds ground water recharge or if it leads to a contamination of ground- or surface water. According to the Intergovernmental Panel on Climate Change (IPCC) irregular and reduced precipitation will quadruple the number of people affected by water shortages in Africa by the year 2050 to more than 250 million (IPCC, 2007). Low levels of irrigation in agriculture and efficiency in water use limit agricultural production growth.

The effects of global warming are already appear to be destroying harvests and threatening food security in Africa. There are five major effects of climate change on agriculture: First, the increases in the concentration of $\mathrm{CO}_{2}$ in the atmosphere, which can in turn lead to a fertilization effect; second, higher average temperatures and third, changes in the availability of water, which are expected to have strong yet different regional effects. Fourth is the increased weather extremes and fifth, higher soil degradation that can lead to significant harvest losses (Dusseldorp \& Sauter, 2011). The expected rise in droughts for already dry regions and the higher risk of flooding wetlands will present Africa with higher risks for famine. Globally, the entire agricultural yield potential is not expected to change significantly by 2080 due to the effects of climate change, yet predictions for Africa are negative. By 2020, crop yields from rain-fed agriculture, which accounts for $90 \%$ of farming, in some African countries are projected to decline by up to $50 \%$ (IPCC, 2007). The United Nations Environment Program reports that the total of climate-related decline in agricultural production will be as much as $10 \%$ in southern Africa (UNEP, 2008a).

Further reducing local availability of food post-harvest losses amount to about one-third of the total harvest volume (Note 7). In southern and eastern Africa, the post-harvest losses in cereals alone are 10-30\%. In Tanzania, about 60 million liters of milk ( $16 \%$ of the total production in the dry season and $25 \%$ in the rainy season) are lost (UNSCN, 2010). Large post-harvest losses are caused by lack of investment in harvesting technology and storage facilities, improper handling and transport, and poor infrastructure. Even in densely populated areas in parts of Southern Africa it may take more than five hours to reach the nearest market (Nellemann et al., 2009). Much of the post-harvest losses could be prevented with existing technology if invested locally, but weak institutions and political instability in some countries discourage investments.

Another key factor that contributes to a decline in agricultural productivity is low spending on research and development (R\&D) in agriculture. While other developing countries recorded an increasing trend, the real expenditure on agricultural R\&D in southern Africa has been decreasing. In 1981, the expenditures were at 
US\$1.15 billion; in 2000 they decreased to US\$0.87 billion (UNEP, 2008b). In addition, protected agricultural markets reduce profits in the sector and thereby limit investments. Rosegrant et al. (2001) calculate that global trade liberalization in the agricultural sector would allow for an estimated US\$4.4 billion in additional income in Sub-Saharan Africa (US\$22 billion for all developing countries). However, depending on comparative advantages, a strategy of export growth within a weak national regulatory framework can negatively affect environmental sustainability.

On the demand side the weak purchasing power of the Sub-Sahara African populations slows down progress. Poverty not only causes low demand, it also increases environmental degradation. Bai et al. (2008) find a positive correlation between the degradation of land and poverty. This relationship is explained by the attempt of the resource poor to be self-sufficient, without concerns for the environment. At the same time environmental degradation is taking away the most important resource from the poor and thereby reinforces their poverty, producing a vicious circle. Environmental degradation is a major limiting factor of agricultural productivity growth. When soils are subject to unsustainable exploitation in the course of food production, these processes limit their suitability for or impede further use (through erosion, salinization, acidification, compaction, contamination with toxic substances and the loss of soil organic matter). A sustainable agriculture must at least maintain, and best promote soil fertility. Since agricultural use generally leads to a net discharge of nutrients from the soil, they have to be replaced through organic or mineral fertilizers. The protection of soil fertility requires a long-term investment. Unclear and weak property rights in land reduce incentives to invest in the resource land, and to take measures to improve the soil and prevent erosion (e.g. Abdulai et al., 2010). Investments in land in turn affect farming yields, which are higher for users with secure land rights than for users with insecure land rights.

The climatic and economic factors mentioned combined with the low prices for land in Sub-Sahara Africa, make farmland attractive to investors. Financially strong state and private investors have recently been either long-term leasing or purchasing large areas of productive farmland. The economic, environmental and social consequences of such investments are controversial. On the one hand, the agricultural policy in Sub-Sahara Africa has been neglected so that there is a strong need for investment. On the other hand, there is not only an unstable food security situation, but also unclear property rights and weak government control and regulation in many Sub-Sahara African countries. Contracts for land can thereby place both the local population and the environment at a disadvantage. Unregulated land use can either lead to degradation and erosion, high greenhouse gas emissions, and overuse of the water supply or take advantage of unexploited harvest potentials, increase productivity and food security. The local population may lose their land without adequate compensation or they may profit from better infrastructure and new employment possibilities in rural areas.

Climate change and agriculture share a reciprocal relationship: on the one hand, climate change affects agricultural production. Changes in rainfall, temperature and other climatic factors are expected to negatively affect food production in Sub-Sahara Africa (see section 2). On the other hand, agriculture influences climate change in several ways.

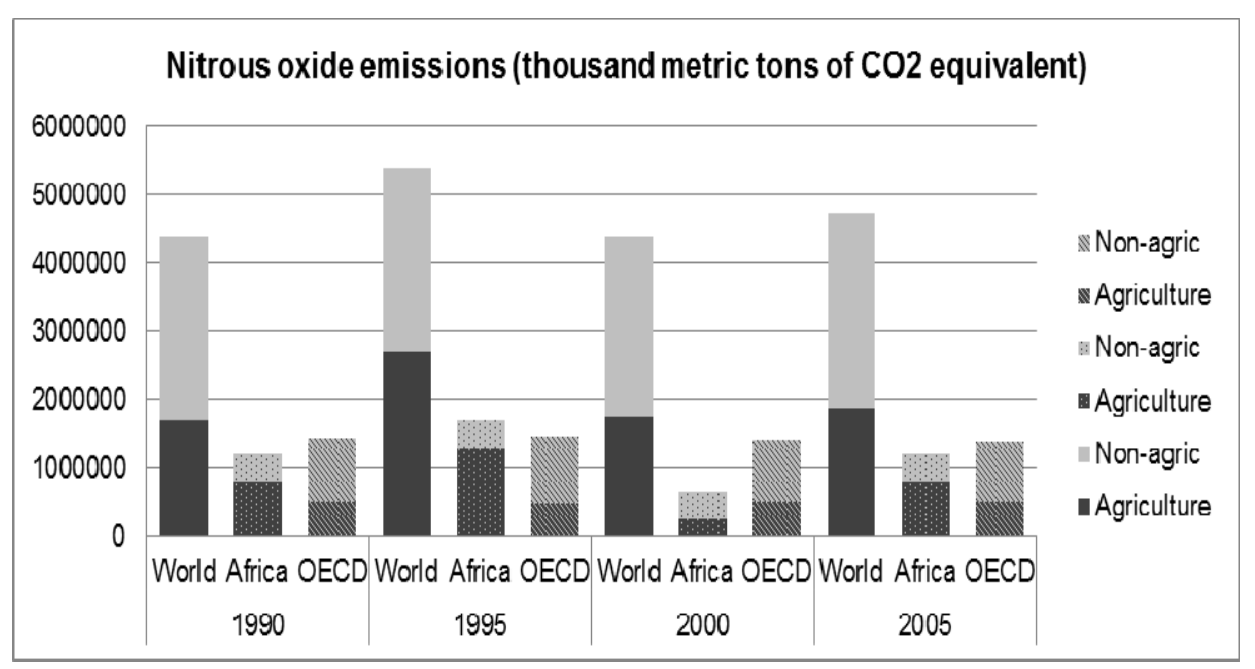

Figure 2. Comparative nitrogen oxide emissions from agriculture

Source: own representation, data from the World Bank: World Development Indicators. 
On the polluter side global agriculture plays an important role and thereby influences future climate change also in Sub-Saharan Africa. About one-third of all global greenhouse gas emissions come from farming (UNEP, 2008a), where the emissions from the livestock industry are in the most critical position since it claims $70 \%$ of agricultural land in the world (IAASTD, 2009). Figure 2 shows the nitrogen oxide emissions for different world regions. Africa has the lowest amount of emissions. However, agriculture has a far bigger share in this region than in richer regions of the world (Note 8).

This overview shows that there are many, partly competing aspects of sustainability. For instance and as explained in this section, economic unsustainability poverty can be a driver of environmental unsustainability and environmental unsustainability can be a driver of poverty. It has also shown that the situation in Sub-Sahara Africa is particular due to its geographic, climatic and demographic situation and its prevalent poverty. In all three dimensions there are critically weak points in Sub-Sahara Africa highlighted in this section. Most solution proposals cover one of these aspects of sustainability and have an indirect effect on other aspects.

\section{Solution Proposals and the Example of Organic Farming}

\subsection{Solution Proposals}

There are a number of partly competing proposals that prioritize different aspects of sustainability differently and are suitable for different local conditions. The following proposals have been mentioned repeatedly in the literature over at minimum the last 15 years. First, as traditionally most poor work in farming, many researchers believe that growth in the agricultural sector is the most effective way to reduce poverty and thereby increase food security (e.g. Dewbre et al., 2011; Byerlee et al., 2009; Thirtle et al., 2003). But whether this is done best by the establishment of large farms or supporting existing smallholders is a critical point of disagreement between scientists. In well-connected areas close to larger cities contract farming might be appropriate, whereas in remote areas with little infrastructure larger farms may work better. Second, amongst others the Alliance for a Green Revolution for Africa promotes a package of high-yielding varieties, increased use of inputs and better access to markets and financial services. Whether or not genetically engineered crops should be part of such a strategy is subject to intense debate. Amid the potential benefits are high-yielding crops that grow under adverse environmental conditions and on so far unsuitable lands. Opponents point towards the risks of reducing genetic diversity and contamination of the natural environment. In addition, this proposal only works if markets function well and crops fit local preferences.

Third, adaptation to climate change is also needed, using better technology or expanding cultivated land or compensate through increasing food imports. This solution would target the use of plants that can adapt to new climate conditions and the adjustment of agricultural methods, such as the timing of sowing and the use of water. Additionally, agroforestry has the potential to mitigate the effects of climate change (IAASTD, 2009). Agro-climatic zones, not national borders, form the reference point for specific measures.

Fourth, among the less contested proposals for ways forward is a strong increase in agricultural research, education and extension services. The CAADP (Comprehensive Africa Agriculture Development Program) under the supervision of the African Union agreed on a target mark of $1 \%$ of the income in agriculture to be spent for agricultural research as well as $10 \%$ of the total government budget that should be put into agriculture in general. Most of the participating countries do not achieve these targets yet, but there is a positive development (Omilola et al., 2010). Industrialized countries could also invest more in research, in particular to reduce the latent conflict between environmental protection, resource conservation and food security. IFPRI suggests that $20-30 \%$ of global development assistance should be channeled into agriculture to ensure food security (von Braun et al., 2008). Fifth a reduction of trade restrictions by developed countries and a decrease in subsidies for the domestic agricultural industry is supposed to benefit the agricultural sector in Africa in general.

Sixth, one solution proposal, organic agriculture, will be discussed in more detail and with special attention to local circumstances and alternatives in Sub-Sahara Africa. Conversion to organic agriculture in Africa is promoted by a range of non-governmental organizations, development cooperation projects and entrepreneurial initiatives. As the name suggests, it is aimed at principally environmental sustainability. The central theme of organic farming is conducting economic activity in accordance with the principles of ecosystems. This allegedly leads to improved (social, environmental and economic) sustainability (Lampkin \& Padel, 1994). Besides the production of food, raw materials or energy, agriculture is responsible for environmental and resource protection. Instead of relying on the principle of output maximization, as used in conventional agriculture, inputs are optimized. Nutrients should be used in quasi-closed cycles. These principles lead to a focus on the use of local resources and the avoidance of external inputs where possible. Organic farming also seeks to increase productivity but only as long as intensification of production is compatible with sustainability. Critiques argue 
that this makes it incompatible with increasing food security.

Due to its similarity to the traditional local agriculture, the transition to organic farming is supposed to be particularly easy to achieve for poor farmers that live in remote areas. Additionally, converting to organic farming supposedly eliminates the dependence on expensive fertilizers and pesticides. Whereas uncertified produce usually serves the local market, certified organic produce in Africa is almost exclusively allocated to the export market. Europe and North America account for $97 \%$ of the world market (Willer \& Kilcher, 2009), and the market is growing rapidly in these regions. Many studies have demonstrated the willingness of consumers to pay a higher price for organic products (e.g. Bjorner et al., 2004; Loureiro \& Hine, 2002; Nimon \& Beghin, 1999). Hence, certified organic produce offers a potentially attractive market in the North. This is why in Africa most certified organic produce is certified according EU or US organic regulations. So far, there has been little research into the demand for organic - certified or uncertified - produce within Africa.

When limited resources such as phosphate and the rising costs of energy-intensive production of mineral fertilizers to lead to increases in production costs and farmers in marginal areas of Africa face already high costs due to poor infrastructure, the substitution of artificial fertilizers with organic compost can be not only an ecological, but also an economic advantage. However, the local availability of organic nutrients varies with the prevalence of livestock production.

\subsection{Economic Dynamics of Organic Agriculture}

The yield potential of organic farming in locations with medium and low soil productivity, especially in the tropics and subtropics, is perceived to be equal or superior to that of conventional production at the present state of knowledge. This is due to the fact that inputs used in conventional farming are often used in low quantities or not at all by farmers in these regions that the effectiveness of mineral fertilizers on soils with low nutrient retention capacity is reduced, and that high-yielding varieties are often unsuitable for cultivation in sub-optimal locations. According to Dusseldorp and Sauter (2011), the great variance in results in empirical studies comparing yields from conventional and organic production indicates that the potential for intensifying ecological production is underutilized in comparison to conventional production and that widespread view that organic farming could only feed a small proportion of the world's population is a preliminary judgment based on limited data.

A number of scientific studies have employed case studies to examine the economic consequences of a conversion to organic farming and organic certification for small farmers in developing countries. Even if, due to the methodology employed in the studies, it is not always clear whether the results stem from the actual conversion, or from other aspects, e.g. unobservable characteristics of the farmers, generally a cautious positive image emerges from the results. A study by Pretty and Hine (2001) that observes a group of 208 sustainable agriculture projects in Africa, Asia and Latin America, shows that sustainable agriculture can increase yields and visibly improves the overall nutritional condition of small farmers. In the 45 projects examined in 17 African countries, the production volume of the farms increased in all cases. Also, according to Pretty (1999), natural and human capital, which are the basis for the sustainability of projects, were accumulated. Overall, most studies find that because of higher prices from certified organic products, small farmers profit more from certified organic, than from conventional farming, while production costs are similar to those of conventional production (Note 9) (e.g. Bolwig et al., 2009; Maertens \& Swinnen, 2009). Hence, those farmers that manage to meet the certification requirements and quality standards of the international market are most likely to benefit.

The question of whether and under what circumstances a significant number of farmers are able to meet these standards, has a mixed answer. The literature gives us both positive and negative examples (e.g. Markelova et al., 2009; Roy \& Thorat, 2008; Wollni \& Zellner, 2007). The cost of certification alone is generally not affordable for small farmers or cooperatives in Sub-Sahara Africa without substantial support by governments, businesses or aid programs (Note 10).

Furthermore, the high level of management and knowledge intensity of organic farming can be an important entry barrier for poorly educated farmers with limited access to information systems and poor links to other farmers in similar situations and is often a reason for the breakdown of organic agriculture initiatives in Sub-Sahara Africa. This problem is also reflected in the low yields that are reported in many scientific studies on organic compared to conventional small-scale farms in Africa despite the aforementioned yield potentials.

Organic and sustainable agriculture are often equated colloquially. However, several tests have shown that organic agriculture plus minor use of chemical inputs often reach the best results in terms of yield and environmental compatibility in an African context, and thus could be called sustainable, too, in particular in areas with little livestock. On the downside in this case the option of certification and thereby to achieve higher prices 
is no longer applicable.

\subsection{Social Dynamics of Organic Agriculture}

With respect to the improvement of the nutritional situation of the disadvantaged and rural population that are mainly peasant farmers, it seems that organic agriculture can empower them to increase their production with limited productive resources, to decrease their production risk by enhancing the diversity of their cultivation systems and therefore to contribute to adapting to climate change. Furthermore, the higher labor intensity and lower capital intensity of organic agriculture can have a positive impact on employment opportunities in rural areas. Studies have shown that by refraining from using chemicals a positive impact on the health of farmers (fewer symptoms of poisoning, less water-related health issues) could be observed.

Cultural proximity to traditional agriculture is often highlighted by supporters. However, this aspect is hard to investigate empirically. Nevertheless, organic agriculture is better suited for (traditional) small and medium-scale diversified farms than for large-scale specialized plantations. Hence potentially, the poorer parts of the rural population, respectively small-scale farmers, could benefit disproportionately from investments in the sector. If the yield potential of organic agriculture would be utilized, the availability of food would increase where access to food is the limiting factor for food security. Likewise, the above mentioned support of small-scale farmers with new production technologies, and the distribution of agricultural knowledge and training act in a similar fashion as investments in education of the rural population.

\subsection{Environmental Dynamics of Organic Agriculture}

Obviously, abstaining from the use of chemical additives has a positive impact on the environment through lower pollution. This positive aspect is particularly important in Sub-Sahara Africa, because improper use of chemicals in agriculture by small-scale farmers is very common, including the use of excessive amounts, insufficient safety measures during application, careless storage and use of highly toxic outdated substances.

Since agricultural use leads to a net outflow of nutrients from the soil, especially when crop production and livestock are spatially separated, nutrients have to be supplied through organic or mineral fertilizer to preserve soil fertility and thus the yield potential of the soil. Small-scale farmers in developing countries often fail in doing so. There is a tendency that farmers which are getting certified are those who practice so-called 'organic by default' agriculture, i.e. traditional shifting cultivation without or with low addition of nutrients. From an environmental point of view, this method will only be sustainable if the fallow period is long enough, which is rarely anymore the case due to an increasing population density and resulting shortage of land. In the present circumstances, this method leads to leaching of soils. So far no scientific studies exist that can affirm or reject this hypothesis on the basis of data on the nutrient content of agricultural soils. However, there are many studies, including those named in the last section that suggest that the principles of organic agriculture are understood and taught as negative laws in Sub-Sahara Africa. Little importance is given to positive instructions, of what one should do to maintain soil fertility. In this respect, organic farming in Sub-Sahara Africa has a vast untapped potential. This type of agriculture can have positive effects on the protection of resources, of the soil and the biodiversity if the application of the principle of the closed nutrient cycle is applied. A number of studies such as Niggli and Kasterine (2007) and UNCTAD (2006) have also shown that organic agriculture does better than conventional agriculture in adaptation to and prevention of climate change. Through a better $\mathrm{CO}_{2}$-balance, organic farming can mitigate the effects of climate change. The amount of emissions per hectare is significantly lower; however they are similar or higher per unit of output. In addition, organically managed soils absorb more $\mathrm{CO}_{2}$ (carbon sequestration) (Niggli \& Kasterine, 2007). Furthermore, adapting to climate change seems easier using organic farming because the induced diversification spreads risk and more robust varieties are grown (UNCTAD, 2006; Stolze et al., 2000).

Some authors conclude that practicing organic farming in conformity with its holistic principles leads to synergies that only come through the interplay of several factors (e.g., Pretty, 1999; Shiferaw \& Holden, 1999). The change of single factors- a ceteris paribus approach -, for example the introduction of water conservation practices through terraces without making improvements at other points of the system at the same time is much more ineffective and possibly unprofitable than if several factors are changed together. In this example this could be the further simultaneous use of improved organic fertilizer to increase productivity and the improvement of access to the credit market to finance the new activities. Again, what combination is suitable depends on local conditions.

\subsection{Adoption and Diffusion of Organic Agriculture}

The number of certified small-scale farmers is relatively high. In 2009, Uganda was, after India, the country with 
the second largest number of certified producers in the world, and Ethiopia, Tanzania and Burkina Faso were also ranked in to the top ten (Willer \& Kilcher, 2009). However organic-certified agricultural land remains limited despite intensive research and mostly positive observed impacts and untapped potentials of organic agriculture (see Figure 3).

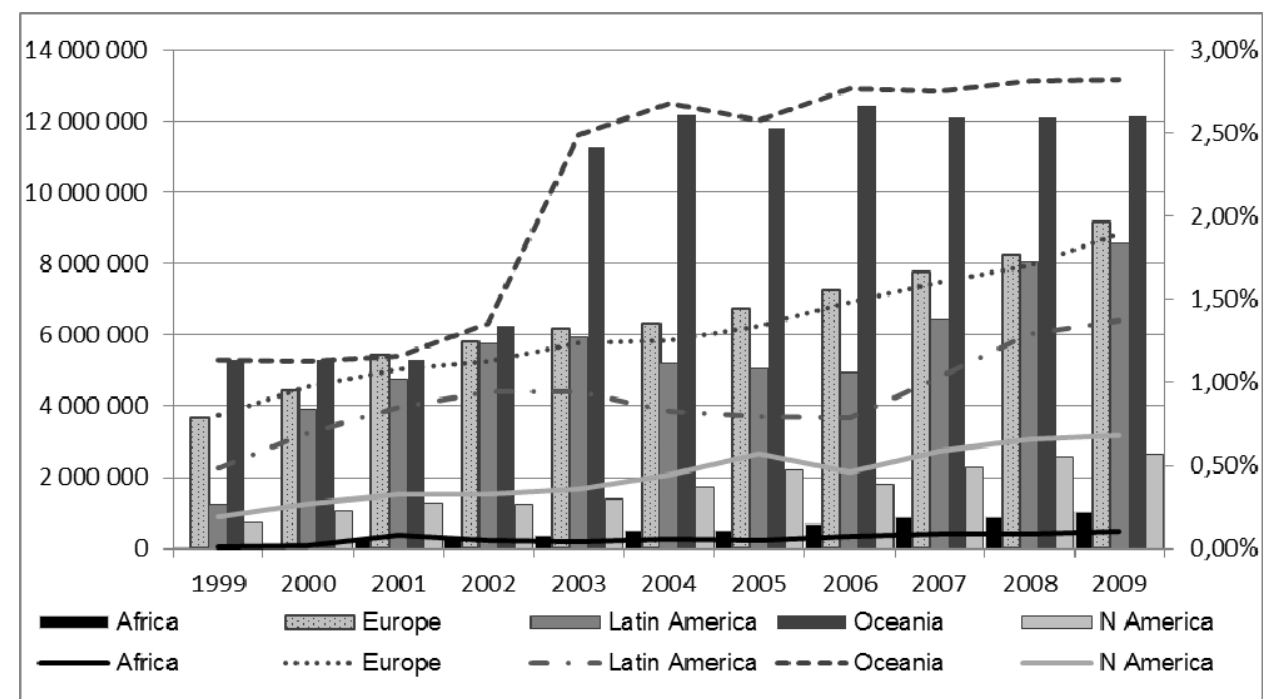

Figure 3. Development of organic certified area worldwide

(In hectares and percentage of the total agricultural land)

Source: own illustration using data from the Research Institute of Organic Agriculture FiBL and International Federation of Organic Agriculture Movements IFOAM (2011).

There is a vast literature on the adoption and diffusion of agricultural technologies in developing countries (see e.g. Feder et al., 1985; Feder \& Savastano, 2006; Foster \& Rosenzweig, 1995, 1996, and 2010) trying to explain this phenomenon. Scientific studies have identified several typical barriers to agricultural technology adoption which can be summarized in six groups: biophysical characteristics of farms, complexity of the technology, household features, poverty of the land tenants, property rights, and input and output markets. The width of this list shows that the spread of organic agriculture can stagnate at many points. The complexity of organic agriculture that exists due to its holistic approach is one of the reasons why its realization can be difficult or at least lengthy. A lot of support programs and initiatives take up single aspects such as the certification. They also often do not accompany the whole process of conversion (Note 11). If the parts are interdependent, this strategy is not very helpful.

The time-lag of organic agriculture is a disadvantage. Many of the positive effects only become visible in the long-term, amongst others because soil fertility changes slowly. In the certification system this reflects in the three-year transitional period before products can be sold as organic certified.

Furthermore there are other aspects that can have a great impact on the diffusion of organic agriculture. One of these aspects is the role and functioning of collective institutions such as cooperatives which are frequently used to disseminate agricultural technologies and organize the process of certification for small-scale farmers. The investigation of the question how farmers or farm households decide for or against a new technology such as organic agriculture within an entity of new and old technologies, institutional environment, market conditions, available resources, and cultural factors and social networks, cannot be derived from traditional theoretical models of agricultural household (e.g. de Janvry et al., 1991). For instance, higher prices for final goods can have very diverse impacts. The return of land and labor increase and thereby encourage investments in agriculture. This can be new technologies that improve soil fertility. But higher prices can also cause the opposite and aggravate ecological damage. If these prices are not expected to be non-permanent, or the discount rate in the future is very high, it may make more sense for the farmer to leach the soil in order to make a higher profit quickly rather than investing in more sustainable long-term technologies.

The problem of slow diffusion is not just a problem of organic agriculture but many technologies in Sub-Sahara Africa and other developing countries. Therefore, a number of researchers currently try to answer questions 
about barriers to adoption and diffusion, and the question of individual profitability of new technologies (e.g. Suri, 2011). Strategically, the idea is not to adopt what has worked well in other regions, but to develop a system that will be the best in the future for this region. Best, from the viewpoint of this article, is considering not only economic efficiency.

\section{Concluding Remarks}

The increase in the number of both undernourished and malnourished people in Sub-Saharan Africa over the last decade has intensified the calls for measures to help boost agricultural productivity and output in order to enhance the food security situation in the region. The challenge for Sub-Sahara African agriculture is therefore substantial. Alongside this challenge to find ways to increase food and livestock production are concerns about agricultural sustainability, as an unprecedented combination of pressures are emerging to threaten the sustainability of existing social and ecological systems. The continuing population growth, impacts of climate change and environmental degradation that are driving the limited resources towards their thresholds need to be taken into consideration in the development of sustainable production techniques.

This article discusses the challenges of meeting the food security and sustainability in agriculture. Given that sustainable development is a concept that includes economic, social and environmental dimensions of conservation, the dual goals of ensuring food security and promoting sustainable production are achievable in the African context only with the right policy mix. The article uses organic farming as one example for a sustainable development strategy for Sub-Sahara African agriculture and nutrition. Its big advantage is its involvement of all three sustainability criteria, but due to its complexity it has weaknesses, especially in implementation.

The study by Pretty and Hine (2001) which analyzed some projects involved in sustainable intensification showed that, provided there is a political and economic domestic recognition that agriculture matters, then food production can be increased without doing harm to the environment and increasing the flow of beneficial environmental services. In principle, organic farming is one possible approach to create a more sustainable agriculture. However as shown above, not only the properties of the solution proposal itself matter, but also the conditions for its adoption and diffusion.

On the market of ideas organic agriculture has to stand up to other strategies for action that promote their sustainability and come with other advantages and disadvantages. In a given political and institutional situation various strategies appear attractive in different ways. However, there are general principles that are considered important to recognize when selecting between alternatives. First, no strategy should work against food security, that is, the sufficient production of and access to food. Second, natural resources, a clean environment, human health and social justice are basic aspects for a functioning agriculture as well as for social and environmental sustainability. In the past, the development of the agriculture often focused singularly on increasing productivity. Third, future strategies have to acknowledge the multifunctionality of agriculture and take into account the complexity of agricultural systems within different socio-economic and environmental situations. Farmers are not just producers but also managers of ecosystems. The incentive systems for all actors in the agricultural sector and for consumers have to be changed in a way that they address this multifunctionality. In the sense of social sustainability, activities have to be geared more towards previously disadvantaged social strata such as farmers with limited resources.

To choose the right strategy mix, all possible economic, social and ecological consequences should be evaluated and used as basis for decisions. The weighting of individual advantages and disadvantages is necessarily a subjective one and depends on the institutional, political, societal and natural context.

\section{References}

Abdulai, A., Owusu, V., \& Goetz, R. (2011). Land tenure differences and investment in land improvement measures: Theoretical and empirical analysis. Journal of Development Economics, 96(1), 66-78. http://dx.doi.org/10.1016/j.jdeveco.2010.08.002

Aksoy, M. A., \& Isik-Dikmelik, A. (2008). Are Low Food Prices Pro-Poor? Net Food Buyers and Sellers in Low-Income Countries. Policy Research Working Paper No. 4642. World Bank, Washington, DC. http://dx.doi.org/10.1596/1813-9450-4642

Amanor, K. S. (2012). Land Governance in Africa - How historical context has shaped key contemporary issues relating to policy on land. International Land Coalition, Framing the Debate Series, no. 1. ILC, Rome.

Anseuw, W., \& Alden, C. (2010). The Struggle over Land in Africa: Conflicts, Politics \& Change. Cape Town: HSRC Press. 
Arezki, R., \& Brückner, M. (2011). Food Prices and Political Instability. IMF Working Paper WP/11/62, International Monetary Fund.

Bai, Z. G., Dent, D. L. Olsson, L., \& Schaepman, M. E. (2008). Proxy global assessment of land degradation. Soil Use and Management, 24, 223-234. http://dx.doi.org/10.1111/j.1475-2743.2008.00169.x

Barrett, C. B., Bachke, M. E., Bellemare, M. F., Michelson, H. C., Narayanan, S., \& Walker, T. F. (2012). Smallholder Participation in Contract Farming: Comparative Evidence from Five Countries. World Development, 40(4), 715-730. http://dx.doi.org/10.1016/j.worlddev.2011.09.006

Benson, T., Minot, N., Pender, J., Robles, M, \& von Braun, J. (2013). Information to guide policy responses to higher global food prices: The data and analyses required. Food Policy, 38, 47-58. http://dx.doi.org/10.1016/j.foodpol.2012.10.001

Benson, T., Mugarura, S., \& Wanda, K. (2008). Impacts in Uganda of rising global food prices: the role of diversified staples and limited price transmission. Agricultural Economics, 39, 513-524. http://dx.doi.org/10.1111/j.1574-0862.2008.00356.x

Bjorner T., Hansen, L., \& Russell, C. S. (2004). Environmental Labelling and Consumers' Choice - An Empirical Analysis of the Effect of the Nordic Swan. Journal of Environmental Economics and Management, 47(3), 411-434. http://dx.doi.org/10.1016/j.jeem.2003.06.002

Bolwig, S., Gibbon, P., \& Jones, S. (2009). The economics of smallholder organic contract farming in tropical Africa. World Development, 37(6), 1094-1104. http://dx.doi.org/10.1016/j.worlddev.2008.09.012

Byerlee, D., Janvry, A. de, \& Sadoulet, E. (2009). Agriculture for Development: Toward a New Paradigm. Annual Review of Resource Economics, $1, \quad 1$, 15-35. http://dx.doi.org/10.1146/annurev.resource.050708.144239

Deaton, A. (2003). Health, Income, and Inequality. NBER Reporter: Research Summary Spring 2003. Retrieved from http://www.nber.org/reporter/spring03/health.html

Dewbre, J., Cervantes-Godoy, D., \& Sorescu, S. (2011). Agricultural Progress and Poverty Reduction: Synthesis Report. OECD Food, Agriculture and Fisheries Working Papers, 49, OECD Publishing. http://dx.doi.org/10.1787/5kg6v1vk8zr2-en

Dusseldorp, M., \& Sauter, A. (2011). Forschung zur Lösung des Welternährungsproblems - Ansatzpunkte, Strategien, Umsetzung. Endbericht zum TA-Projekt (Büro für Technikfolgen-Abschätzung beim Deutschen Bundestag). Retrieved from http://www.tab-beim-bundestag.de/de/pdf/publikationen/berichte/TAB-Arbeitsbericht-ab142.pdf

De Janvry, A., Fafchamps, M., \& Sadoulet, E. (1991). Peasant Household Behaviour with Missing Markets: Some Paradoxes Explained. The Economic Journal, 101(409), 1400-1417. http://dx.doi.org/10.2307/2234892

Feder, G., \& Savastano, S. (2006). The Role of Opinion Leaders in the Diffusion of New Knowledge: The Case of Integrated Pest Management. World Bank Policy Research Working Paper 3916, The World Bank, Washington, DC. http://dx.doi.org/10.1596/1813-9450-3916

Feder, G., Just, R., \& Zilberman, D. (1985). Adoption of Agricultural Innovations in Developing Countries: A Survey. Economic Development and Cultural Change, 33, 255-298. http://dx.doi.org/10.1086/451461

Fergusson, L. (2013). The Political Economy of Rural Property Rights and the Persistence of the Dual Economy. Forthcoming in Journal of Development Economics, 103, 167-181. http://dx.doi.org/10.1016/j.jdeveco.2013.02.009

Flachowsky, G. (2011). Globale Ernährungssicherung: Stand und Herausforderungen. Novo Agrumente, 112, 188-200. Retrieved from http://www.novo-argumente.com/magazin.php/novo_notizen/artikel/000832

Foster, A. D., \& Rosenzweig, M. R. (1995). Learning by Doing and Learning from Others: Human Capital and Technical Change in Agriculture. Journal of Political Economy, 103(6), 1176-1209. http://dx.doi.org/10.1086/601447

Foster, A. D., \& Rosenzweig, M. R. (1996). Technical Change and Human Capital Returns and Investments: Evidence from the Green Revolution. American Economic Review, 86(4), 931-953.

Foster, A. D., \& Rosenzweig, M. R. (2010). Microeconomics of Technology Adoption. Annual Review of Economics, Annual Reviews, 2(1), 395-424. http://dx.doi.org/10.1146/annurev.economics.102308.124433 
Gilbert, C. (2010). How to understand high food prices. Journal of Agricultural Economics, 61(2), 398-425. http://dx.doi.org/10.1111/j.1477-9552.2010.00248.x

Intergovernmental Panel on Climate Change (IPCC). (2007). Climate Change 2007: Synthesis Report. Pachauri, R. K. and A. Reisinger (Eds.). Geneva, Switzerland, Retrieved from http://www.ipcc.ch/pdf/assessment-report/ar4/syr/ar4_syr.pdf

International Assessment of Agricultural Knowledge, Science and Technology for Development. (IAASTD). (2009). Agriculture at a Crossroads. In B. D., McIntyre, H. R. Herren, \& J. R. T. Wakhungu, Watson.Washington, DC: Island Press.

International Food Policy Research Institute (IFPRI), Concern Worldwide, and Welthungerhilfe. (2011). Global Hunger Index 2011- The Challenge of Hunger: Taming Price Spikes and Excessive Food Price Volatility. October 2011, Bonn, Washington, DC, Dublin.

Kelatwang, S., \& Garzuglia, M. (2006). Changes in forest Area in Africa 1990-2005. International Forestry Review, 8(1), 21-30. http://dx.doi.org/10.1505/ifor.8.1.21

Lampkin, N., \& Padel, S. (1994). The Economics of Organic Farming - An International Perspective. Wallingford: $\mathrm{CAB}$ International.

Loureiro M. L., \& Hine, L. (2002). Discovering Niche Markets: A Comparison of Consumer Willingness to Pay for Local (Colorado Grown), Organic, and GMO-Free Products. Journal of Agricultural and Applied Economics, 34, 477-87.

Maertens, M., \& Swinnen, J. F. (2009). Trade, Standards, and Poverty: Evidence from Senegal. World Development, 37(1), 161-178. http://dx.doi.org/10.2139/ssrn.950485

Markelova, H., Meinzen-Dick, J., Hellin, \& Dohrn, S. (2009). Collective action for smallholder market access. Food Policy, 34(1), 1-7. http://dx.doi.org/10.1016/j.foodpol.2008.10.001

McArthur, J. W. (2011). Fertilizing Growth: Estimating Agricultural Yields and their Effects in Economic Development. Paper presented at the Oxford CSAE2011 Conference on Economic Development in Africa. Retrieved from http://www.csae.ox.ac.uk/conferences/2011-EDiA/papers/646-McArthur.pdf

Mendez M, \& Popkin, B. M. (2004). Globalization, urbanization and nutritional change in the developing world. Journal of Agricultural and Development Economics, 1(2), 220-241.

Minot, N., \& Dewina, R. (2013). Impact of Food Price Changes on Household Welfare in Ghana, IFPRI Discussion Paper 01245. http://dx.doi.org/10.2139/ssrn.2228922

Nellemann, C., MacDevette, M., Manders, T., Eickhout, B., Svihus, B., Prins, A. G., \& Kaltenborn, B. P. (Eds). (2009). The environmental food crisis - The environment's role in averting future food crises. A UNEP rapid response assessment. United Nations Environment Programme, GRID-Arendal.

Niggli, U., \& Kasterine, A. (2007). Organic Farming and Climate Change. Geneva: Research Institute of Organic Agriculture and International Trade Centre.

Nimon, W., \& Beghin, J. C. (1999). Are Eco-Labels Valuable? Evidence from the Apparel Industry. American Journal of Agricultural Economics, 81, 801-811. http://dx.doi.org/10.2307/1244325

Omilola, B., Yade, M., Karugia, J., \& Chilonda, P. (2010). Monitoring and Assessing Targets of the Comprehensive Africa Agriculture Development Programme (CAADP) and the First Millennium Development Goal (MDG) in Africa. Regional Strategic Analysis and Knowledge Support System (ReSAKSS). ReSAKSS Working Paper No. 31, July 2010, Washington, DC: International Food Policy Research Institute.

Pearce, D. (1988). Economics, equity and sustainable development. Futures, 20(6), 598-605. http://dx.doi.org/10.1016/0016-3287(88)90002-X.

Pesticides Initiative Programme (PIP). (2009). Survey of fresh fruit and vegetable exporters in sub-saharan Africa: Changing buyer requirements and their impact on supply chains. COLEACP PIP, Brussels Belgium, May 2009. Available online at: www.coleacp.org/pip.

Pretty, J. (1999). Can sustainable agriculture feed Africa? New evidence on progress, processes and impacts. Environment, Development and Sustainability, 1, 253-274. http://dx.doi.org/10.1023/A:1010039224868

Pretty, J., \& Hine, R. (2001). Reducing Food Poverty with Sustainable Agriculture: A Summary of New Evidence. Final Report from the "SAFE-World" (The Potential of Sustainable Agriculture to Feed the 
World) Research Project, February 2001. University of Essex: Centre for Environment and Society.

Rosegrant, M., Paisner, M., Meijer, S., \& Witcover, J. (2001). 2020 Global Food Outlook, Trends, Alternatives, and Choices. Washington DC: International Food policy Research Institute.

Roy, D., \& Thorat, A. (2008). Success in high value horticultural export markets for the small farmers: The case of Mahagrapes in India. World Development, 36(10), 1874-1890. http://dx.doi.org/10.1016/j.worlddev.2007.09.009

Sen, A. (1999). Development as Freedom. Oxford: Oxford University Press.

Shiferaw, B., \& Holden, S. (1999). Soil Erosion and Smallholders' Conservation Decisions in the Highlands of Ethiopia. World Development, 27(4), 739-752. http://dx.doi.org/10.1016/S0305-750X(98)00159-4

Stolze, M., Piorr, A., Häring, A., \& Dabbert, S. (2000). The Environmental Impacts of Organic Farming in Europe. Stuttgart-Hohenheim: University of Hohenheim.

Suri, T. (2011). Selection and Comparative Advantage in Technology Adoption. Econometrica, 79(1), 159-209. http://dx.doi.org/10.3982/ECTA7749

Swinnen, J. (2011). The Right Price of Food. Development Policy Review, 29(6), 667-688. http://dx.doi.org/10.1111/j.1467-7679.2011.00552.x

Thirtle, C., Lin, L., \& Piesse, J. (2003). The Impact of Research-Led Agricultural Productivity Growth on Poverty Reduction in Africa, Asia and Latin America. World Development, 31(12), 1959-1975. http://dx.doi.org/10.1016/j.worlddev.2003.07.001

United Nations Conference on Trade and Development (UNCTAD). (2006). Trade and Environment Review. New York and Geneva: United Nations.

United Nations World Commission on Environment and Development (UN-WCED). (1987). Report of the World Commission on Environment and Development: Our Common Future. Oxford: Oxford University Press.

United Nations Environment Programme (UNEP). (2008a). Africa: Atlas of Our Changing Environment. Division of Early Warning and Assessment (DEWA). Nairobi: United Nations Environment Programme (UNEP).

United Nations Environment Programme (UNEP). (2008b). Innovation for Sustainable Development Local Case Studies from Africa Department of Economic and Social Affairs. Division for Sustainable Development. New York: United Nations.

United Nations Standing Committee on Nutrition (UNSCN). (2010). $6^{\text {th }}$ Report on the world nutrition situation. UNSCN Secretariat c/o World Health Organization. Retrieved from http://www.unscn.org/files/Publications/RWNS6/html/index.html.

von Braun, J., Nkonya, E., Gerber, N., Baumgartner, P., de Pinto, A., Graw, V., ...Walter, T. (2011). The Economics of Desertification, Land Degradation, and Drought. Toward an Integrated Global Assessment. IFPRI Discussion Paper 01086.Washington, DC: International Food Policy Research Institute. http://dx.doi.org/10.2139/ssrn.1890668

von Braun, J., Ahmed, A., Asenso-Okyere, K., Fan, S., A Gulati, J., Hoddinott, R., ... von Grebmer, K. (2008). High food prices: The what, who, and how of proposed policy actions. IFPRI Policy Brief. Washington, DC: International Food Policy Research Institute.

von Braun, J. (2001). Ernährung der wachsenden Weltbevölkerung. Vortrag zu Jahrestagung der Akadamie, Zentrum für Entwicklungsforschung (ZEF), Universität Bonn, 31.10.2001.

Willer, H., \& Kilcher, L. (Eds.) (2009). The World of Organic Agriculture. Statistics and Emerging Trends 2009.FIBL-IFOAM Report. Bonn: IFOA; Geneva: FiBL, Frick; ITC.

Wollni, M., \& Zeller, M. (2007). Do farmers benefit from participating in specialty markets and cooperatives? The case of coffee marketing in Costa Rica. Agricultural Economics, 37(3), 243-248. http://dx.doi.org/10.1111/j.1574-0862.2007.00270.x

World Bank. (2008). Rising Food Prices in Sub-Saharan Africa: Poverty Impact and Policy Responses. Policy Research Working Paper 4738. Washington, DC: The World Bank.

World Bank. (2013). Rural-Urban Dynamics and the Millennium Development Goals-Global Monitoring Report 2013. The International Bank for Reconstruction and Development / The World Bank. 


\section{Notes}

Note 1. The MDGs consist of eight goals, each with oneor more sub goals that have been established in 2000 by several international organizations to be achieved by 2015.MDG1 stands for the halving of extreme poverty and hunger, MDG 7 concerns environmental sustainability, MDGs4,5 and6, infant mortality rate, maternal mortality and the combating of major diseases, such as AIDS and malaria.

Note 2. A meat-based diet affects the environmental sustainability negatively, because the direct emissions (through livestock) and the indirect emissions (through fodder production) are on average higher than for the production of plant-based foods, though, the emission level depends, among other things, on the technology used and the location of production.

Note 3. The WHI is based on three values: the proportion of undernourished in the population, the proportion of underweight children under five years old and the mortality rate among children under five years of age.

Note 4. Food security is defined as a state where an individual has at any time physical, social and economic access to sufficient, affordable, safe and nutritious food. Undernourishment is an aspect of food security measured as a state where the human intake of energy from food is below the minimum energy requirement of the body. This requirement is defined by the amount of energy necessary to achieve an acceptable size by weight ratio ("weight for attained height") and perform light physical activity.

Malnutrition is a broad term that includes all forms of malnutrition. It can have many different causes, including infections, and nutritional, and socio-cultural factors. Malnourishment encompasses both the concepts of undernourishment and of obesity (definition from the UNSCN, 2010).

Note 5 . The quantity of food needed to achieve individual food security, the number of humans and their average dietary energy requirements can be used to determine the total amount of food needed.

Note 6 . The link between food prices and small-scale farmer welfare is subject to intense research and political discussions, see for instance Benson et al. (2013), Minot and Dewina (2013), Swinnen (2011), Benson et al. (2008), Aksoy and Isik-Dikmelik (2008).

Note 7. The estimates can be found for instance on the website www.phlosses.net

Note 8 . Nitrogen compounds generate the environmentally harmful substances ammoniac, nitrate and laughing gas (nitrous oxide).

Note 9. Other sustainability standards like fair trade also yield positive results.

Note 10. This is true for the export market in general due to its strict requirements. In addition, certifications such as GLOBALGAP for conventional produce are almost universally in demand in the export of fresh agricultural produce from Africa. For example, $76 \%$ of all fruits and vegetables in the European market are GLOBALGAP certified (PIP, 2009).

Note 11. Even compensation payments that are regularly used in Latin America for carbon sinks have made little difference. Problems with the correct measurement of environmental services by agriculture add to the difficulties.

\section{Copyrights}

Copyright for this article is retained by the author(s), with first publication rights granted to the journal.

This is an open-access article distributed under the terms and conditions of the Creative Commons Attribution license (http://creativecommons.org/licenses/by/3.0/). 